\title{
Petrology, geochemistry and genesis of new Mesoproterozoic high-magnesian calcite-rich kimberlites of Siddanpalli, Eastern Dharwar Craton, Southern India: products of subduction-related magmatic sources?
}

\author{
N.V. Chalapathi Rao ${ }^{1}$, A. Dongre ${ }^{2}$, G. Kamde ${ }^{3}$, Rajesh K. Srivastava ${ }^{1}$, M. Sridhar ${ }^{4}$ and \\ F.V. Kaminsky \\ ${ }^{1}$ Department of Geology, Banaras Hindu University, Varanasi 221 005, India \\ ${ }^{2}$ Department of Geology, Government Institute of Science, Aurangaba , India \\ ${ }^{3}$ Department of Geology, RSTM (Nagpur) University, Nagpur, India \\ ${ }^{4}$ Geological Survey of India, Eastern Region, Kolkata, India \\ ${ }^{5}$ KM Diamond Exploration Ltd., West Vancouver, British Columbia, Canada
}

Siddanpalli kimberlites constitute a newly discovered cluster (SKC) of Mesoproterozoic (1090 Ma; Anil Kumar et al., 2007) dykes occurring in the granitegreenstone terrain of the Gadwal area in the Eastern Dharwar Craton (EDC), Southern India (Sridhar et al., 2004; Fig. 1). These kimberlites are a part of the Raichur kimberlite field (RKF) and are located between the Narayanpet kimberlite field (NKF) comprising 30 occurrences, about $65 \mathrm{~km}$ to the North, and the Wajrakarur kimberlite Field (WKF) comprising $\sim 40$ occurrences which is about $100 \mathrm{~km}$ towards the south. Some of the kimberlites from RKF are diamondiferous (Lynn, 2005).

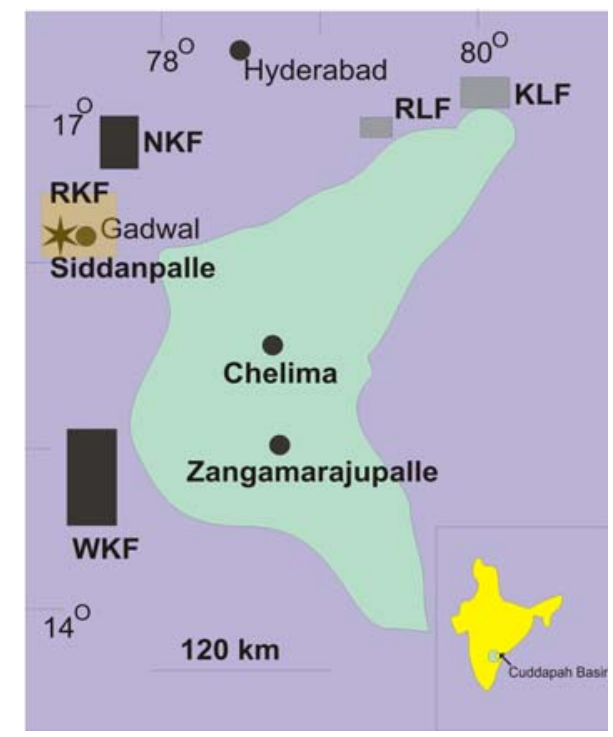

Fig. 1 Geological map of the Cuddapah Basin in EDC, southern India. NKF: Narayanpet kimberlite field; RKF: Raichur kimberlite field; WKF: Wajrakarur kimberlite field; KLF: Krishna lamproite field; RLF: Ramadugu lamproite field.
Siddanpalli kimberlites are the only occurrences located within the Krishna River Basin which has produced, especially in the eastern downstream valley, some of the world famous Indian diamonds, such as Koh-i-Noor, Pitt, Orloff etc. Siddanpalli area had witnessed subduction-related boninitic magmatism during the Neoarchaean (Manikyamba et al., 2005). It would be therefore of interest to investigate whether these long term memories of subduction during Neoarchaean have had any influence on the continental lithospheric mantle at the time of eruption of SKC in Mesoproterozoic.

SKC belong to hypabyssal facies and contain two generations of serpentinized olivines, phlogopite, spinel, perovskite, apatite, carbonate and pyrope garnet xenocrysts. A peculiar feature of these kimberlites is the abundance of carbonate and limestone xenoliths of the eroded platformal Proterozoic (Purana) sedimentary cover of Kurnool/Bhima age (Dongre et al., 2008). Mineral chemistry studies reveal that phlogopite is Tipoor $\left(<0.8\right.$ wt.\% $\left.\mathrm{TiO}_{2}\right)$, Al-rich $\left(16\right.$ wt. $\left.\% \mathrm{Al}_{2} \mathrm{O}_{3}\right)$, and contains a noticeable amount of $\mathrm{Ba}(0.18 \mathrm{wt} \% \mathrm{BaO})$. Apatite contains appreciable amounts of $\mathrm{Sr}$ and $\mathrm{F}$. $\mathrm{La}_{2} \mathrm{O}_{3}$ and $\mathrm{Ce}_{2} \mathrm{O}_{3}$ contents in perovskite are significantly higher than those in apatite demonstrating the major role of perovskite in the REE distribution.

Chemically, the Siddanpalli pipes are the most magnesian-rich (up to $35 \mathrm{wt} \% \mathrm{MgO}$ ) and silicaundersaturated $\left(\mathrm{SiO}_{2}<35\right.$ wt.\%) compared to all kimberlites from the Eastern Dharwar Craton. Low kimberlite contamination indices (viz., C.I. and Ilm. I) are also their characteristic feature. Even though Siddanpalli kimberlitic magma might have assimilated, to some extent, ancient platformal carbonate horizons there is strong evidence, from correlation between $\mathrm{Mg}$ and $\mathrm{Ca}$, for the involvement of primary carbonate in its source.

Despite their high magnesian nature SKC possess the least abundances of compatible elements (e.g. $\mathrm{Ni}, \mathrm{Cr}$ and Co) compared to other EDC kimberlites. On the 
other hand, their incompatible trace element concentrations are similar or relatively much higher than those of the WKF and NKF kimberlites from the Eastern Dharwar Craton (Chalapathi Rao et al., 2004). They display affinities towards the Group I kimberlites as well as to Group II kimberlites of southern Africa in the major and trace element discriminant plots (Fig. 2A and B).

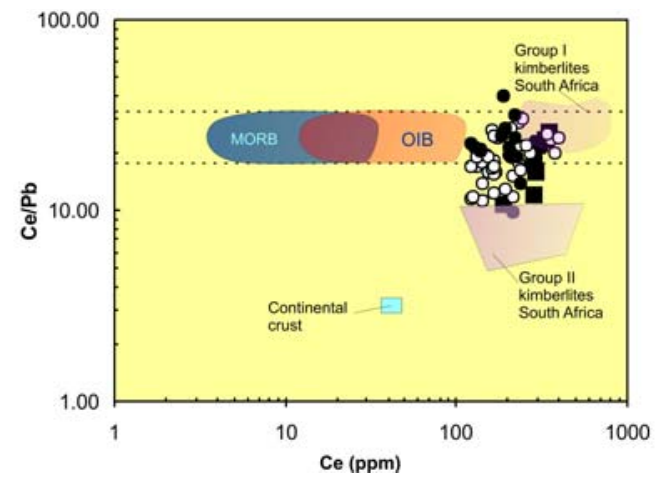

Fig. 2A Group I and II kimberlite affinity of Siddanpalli kimberlites (black squares). Data for other kimberlites from WKF (open cirlces) and NKF (dark circles) is also shown. Fields are taken from LeRoex et al. (2003).

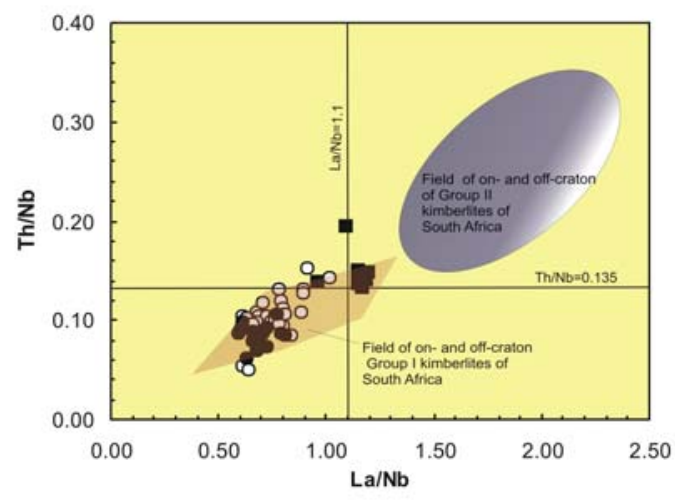

Fig. 2B Siddanpalli kimberlites plot away from other EDC kimberlites. Fields are taken from Becker and Le Roex (2006). Symbols are same as in Fig.2A.

Normalized multi-element plots of SKC reveal that their incompatible trace element are highly enriched over the primitive mantle. $\mathrm{La} / \mathrm{Yb}$ ratio in the Siddanpalli kimberlites (30-90) is considerably lower than that in the other EDC kimberlites (108-145) primarily owing to their much higher HREE abundances (Fig. 3). Since there is no evidence of any significant crustal contamination by country granitoid rocks we infer this to a specific character of the magmatic source.

The degree of partial melting can be estimated from the $\mathrm{SiO}_{2}$ content of a melt and the respective Nb/Y. Fig. 4 demonstrates that the amount of partial melting under gone by SKC source regions is empirically much higher than any of the other EDC kimberlites and also those from southern Africa.
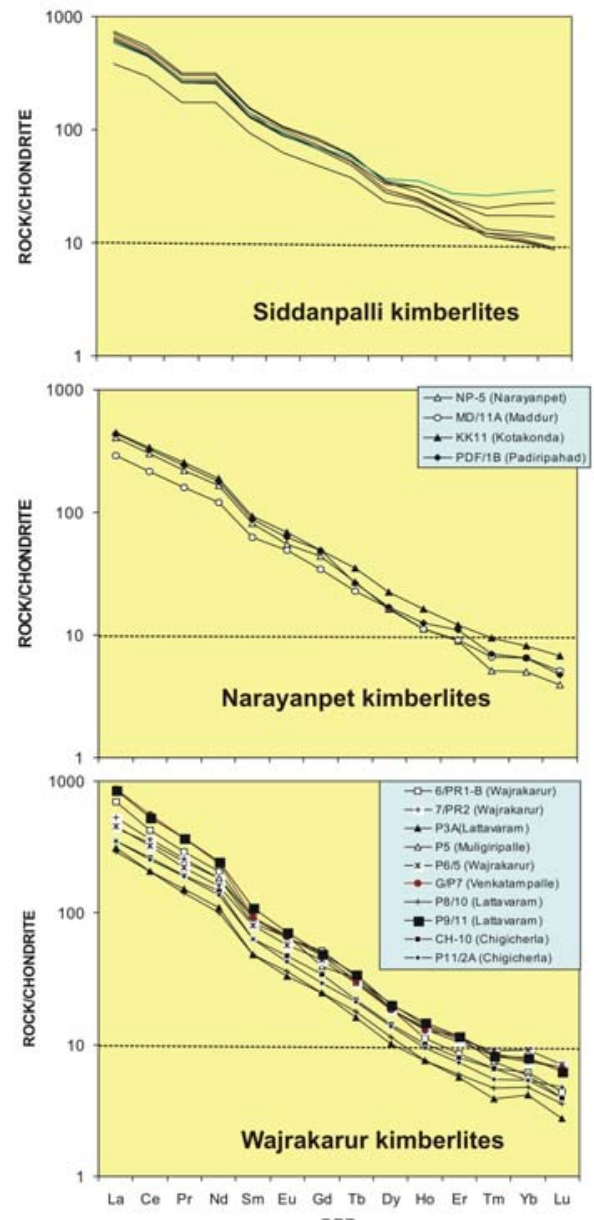

Fig. 3 Chondrite normalized REE patterns of Siddanpalli kimberlites compared with those from Narayanpet and Wajrakarur kimberlites of the Eastern Dharwar Craton, southern India.

Higher HREE abundances can be either interpreted as (i) derivation from relatively shallower depths of origin with less control of residual garnet, (ii) contamination by the country rock granitoids or (iii) due to incorporation of the subducted crustal component in the mantle source region. As mantle-derived garnet xenocrysts are present in SKC and contamination indices (C.I) involving major elements characteristic of granitoids are low, we would prefer the role of possible subducted component contributing higher HREE contents. Reported occurrence of Neoarchaean boninitic magmas (Manikyamba et al., 2005) in the vicinity $(\sim 15 \mathrm{~km})$ of SKC provide evidence for the subduction experienced by this domain in the Eastern Dharwar Craton. A highly refractory mantle that was already depleted in $\mathrm{Ni}, \mathrm{Cr}$ and $\mathrm{Co}$ due to the extraction of high-magnesian boninitic lavas appear to have influenced kimberlite source region(s) and resulted in their relatively lower abundances in the SKC despite the latter's high magnesian nature. 


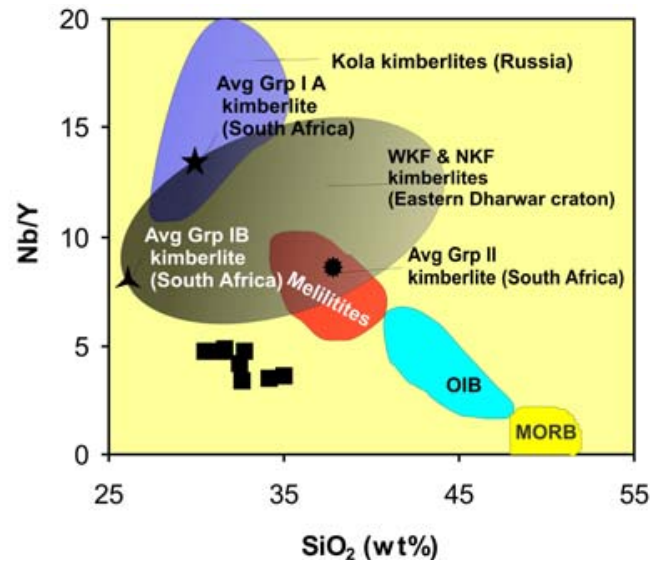

Fig. $4 \mathrm{Nb} / \mathrm{Y}$ vs $\mathrm{SiO}_{2}$ (wt.\%) plot illustrating the degree of partial melting in the kimberlites of this study. Field for EDC kimberlites is from Chalapathi Rao et al. (2004). The other fields are taken from Beard et al. (1998).

A recent study of the geochemistry of Group II kimberlites from southern Africa revealed that they have characteristics similar to the calc-alkaline magmas and are associated with ancient subduction events unrelated to mantle plume upwelling (Becker and LeRoex, 2006). Thus, some of the Group II kimberlite affinities displayed by the SKC could well be due to the long term subduction memories experienced by the continental lithospheric mantle in the Siddanpalli domain.

REE based semi-quantitative forward modeling involving batch melting suggest involvement of heterogeneous sources having characteristics of Group I and II kimberlites as well their hybrid composition is inferred in the SKC genesis. The different geochemical signatures of the SKC compared to the other known kimberlites in the Eastern Dharwar Craton can therefore be explained by a combination of factors involving (i) higher degrees of partial melting, (ii) possible involvement of subducted component in their mantle source region and (iii) previous extraction of boninitic magmas from their geological domain.

\section{References}

Anil Kumar, Anil Kumar, Heaman, L.A., Manikyamba, C., 2007. Mesoproterozoic kimberlites in south India: a possible link to $\sim 1.1 \mathrm{Ga}$ global magmatism. Precambrian Research 15: 192-204.

Beard, A.D., Downes, H., Hegner, E., Sablukov, S.M., Vetrin, V.R., Balogh, K., 1998. Mineralogy and geochemistry of Devonian ultramafic minor intrusions of the southern Kola peninsula, Russia: implications for the petrogenesis of kimberlites and melilitites. Contributions to Mineralogy and Petrology, 130, 288-303.

Becker, M., LeRoex, A.P., 2006. Geochemistry of South African On- and Off-craton Group I and II kimberlites: Petrogenesis and source region evaluation. Journal of Petrology, 47, 673-703.

Chalapathi Rao, N.V., Gibson, S.A., Pyle, D.M., Dickin., AP., 2004. Petrogenesis of Proterozoic lamproites and kimberlites from the Cuddapah Basin and
Dharwar Craton, southern India. Journal of Petrology, 45(5), 907-948.

Dongre, A., Dongre, A, Chalapathi Rao, N.V., Kamde, G., 2008 Limestone xenolith in Siddanpalli kimberlite, Gadwal granite-greenstone terrain, Eastern Dharwar Craton, Southern India: Remnant of Proterozoic Platformal cover sequence of Vhima/Kurnool age? Journal of Geology, 116,184-191.

LeRoex, A.P., Bell, D.R., Davis, P., 2003. Petrogenesis of Group I kimberlites from Kimberley, South Africa: evidence from bulk-rock geochemistry. Journal of Petrology, 44, 2261-2286.

Lynn, M., 2005. The discovery of kimberlites in the Gulburga and Raichur districts of Karnataka. Proceedings of Group Discussion on Kimberlites and related rocks of India. Geological Society of India, 48-49.

Manikyamba, C., Naqvi, S.M., Subba Rao, D.V., Ram Mohan, M., Khanna, T.C., Rao, T.G., Reddy, G.L.N., 2005. Boninites from the Neoarchaean Gadwal greenstone belt, Eastern Dharwar Craton, India: implications for Archaean subduction processes. Earth and Planetary Science Letters, 230, 65-83.

Sridhar, M., Chowdhary, V.S., Nayak, S.S., Augustine, P.F., 2004. Discovery of kimberlite pipes in Gadwal area, Mahbubnagar district, Andhra Pradesh. Journal of Geological Society of India, 63, 95-99. 